\title{
Effect of Paclobutrazol and Its Method of Application on The Growth of Pentas lanceolata Plants
}

\author{
Asmaa M. Taha and Mona A. Sorour \\ Ornamental Plants Research Department, Horticulture Research Institute, ARC, \\ Alexandria, Egypt.
}

\begin{abstract}
This study was carried out during the two successive seasons of 2013 and 2014 at Antoniades Research Branch, Horticulture Research Institute, A.R.C. Alexandria, Egypt . The experiment was carried out to investigate the effect of paclobutrazol ( PBZ) at the concentrations of $(30,60,90$ and $120 \mathrm{mg} / \mathrm{L}$ ) and its application method (drench and spray ) on the growth, flowering and chemical composition of Pentas lanceolata, L. plants. The results showed that all the treatments caused a positive effect on the reduction of the vegetative growth of pentas plants and the treatment of $120 \mathrm{mg} / \mathrm{L} \mathrm{PBZ}$ caused the highest significant reduction on most studied characters of vegetative growth. While there was insignificant effect after PBZ application at all concentrations on the flowering characteristics. For roots dry weight, the chlorophyll content and total carbohydrate content there was a significant increase after the application of PBZ at different concentrations. Drench application of PBZ was more effective than foliar application of in reduction of the most studied vegetative growth characters and increasing roots dry weight, the chlorophyll content and total carbohydrate content.
\end{abstract}

Key wards: Pentas lanceolata L.,paclobutrazol ,soil Dench, foliar spray

\section{INTRODUCTION}

Growth retardants are commonly used in floriculture for height control and increasing the number of lateral shoots or suppressing the growth of shoots developing beneath the flower, resulting in a larger number of inflorescences (Whealy et al., 1988, Keever and Foster 1989).

Plant growers use chemical growth retardants to produce quality plants that can be held in greenhouse if needed, shipped properly, look appealing in the stores and grow out well for the end consumers (Sanchita, 2015).

Paclobutrazol is a plant growth regulator which inhibits the gibberellin biosynthesis or action. It is very effective for dwarfing a wide range of crops including tulips (Lever et al., 1982, Menhenett and Hanks 1982). It is used primarily for reducing the extension of shoot growth, to increase the root growth, produce uniform compact plants, with enhancement of foliage colour and flowering in certain species. The response of plants to paclobutrazol applications differs depending on the time of application, method of application, concentration and plant species (Tsegaw et al., 2005). It is used on ornamental plants grown in containers in nurseries, green houses, shade houses and interior scape in the crops like azaleas, hibiscus, poinsettias, chrysanthemum, and roses. It is mostly applied in the form of drench or spray (Sanchita, 2015).

Pentas lanceolata $\mathrm{L}$. is a common plant, originating from tropical East Africa to Arabia. The most widely used names are "Egyptian Star Cluster" or "Pentas". As a decorative plant, it has been spread all over the tropics and subtropics. The flowers can be white, pink, purple, or red. This species belongs to the family Rubiaceae (Mongrand et al., 2005). 
The aim of this work was to study the effect of paclobutrazol and its application methods on vegetative growth, flowering and chemical composition of Pentas lanceolata.L.

\section{MATERIALS AND METHODS}

The present investigation was carried out during the two successive seasons of 2013 and 2014 at Antoniades Research Branch, Horticulture Research Institute, A.R.C., Alexandria.

Stem cuttings of Pentas lanceolata (semi-hard wood cuttings) with an average length of $15-17 \mathrm{~cm}$ were planted in plastic pots of $10 \mathrm{~cm}$ diameter using a mixture of sand and clay soils at ratio of (1:1 by volume) on $15^{\text {th }}$ March 2013 and $1^{\text {st }}$ April 2014 in the two seasons respectively. After six weeks, each rooted cutting was transplanted in $20 \mathrm{~cm}$ clay pots containing peat moss, clay and sand $(1: 1: 1 \mathrm{v} / \mathrm{v})$. The plants were pinched to the height of $20 \mathrm{~cm}$. and two lateral shoots were left on each plant, while all other shoots or breaks were removed.

Five foliar treatments of paclobutrazol (PBZ) at concentrations of 0,30 , 60,90 and $120 \mathrm{mg} / \mathrm{L}$ were applied till run off point at $20 \mathrm{ml}$ of PBZ per plant. The top of the pot was covered with plastic to keep the medium out of growth retardant contact, all treatments were applied using a hand sprayer.

Five drench treatment of PBZ at the same concentrations were also applied 7 days after of final transplanting. No water was applied for two days before the drenching. Each experimental unit received $90 \mathrm{ml}$ of PBZ solutions. The control plants were sprayed or drenched with water only.

The requirement of plants for fertilization was covered by the addition of NPK chemical fertilization 19-19-19 at the rate of $2.5 \mathrm{~g} /$ pot. Each fertilization dose was repeated at 21 days intervals.

The layout of the experiment was randomized complete block design in a factorial experiment, containing three replicates. The experiment contained 10 different treatments (5 PBZ X 2 methods).

Three pots were used as an experimental unit for each treatment in each replicate. The data were subjected to statistical analysis of variance and the means were compared using the "least significant difference (L.S.D)" test at the $5 \%$ level of probability according to (Snedecor and Cochran, 1989).

The following data were recorded; the vegetative growth parameters including plant height $(\mathrm{cm})$, stem diameter $(\mathrm{cm})$, number of branches /plant , number of leaves/ plant, leaves dry weight (g), stem dry weight (g) and leaf area $\left(\mathrm{cm}^{2}\right)$, roots dry weight $(\mathrm{g})$, The flowering characteristics, included the time taken to showing color stage from planting date (day), flowers longevity (days) as a day from the showing color stage to fading and roots dry weight $(\mathrm{g})$, Chemical analysis of fresh leaf samples at showing coloring stage was conducted to determine their leaves total content of chlorophyll ( $a$ and b) $(\mathrm{mg} / \mathrm{g}$ fresh weight) as described by Moran (1982). Also, total carbohydrate content in dried leaf samples was determined according to Dubios et al.(1956) in the second season. 


\section{RESULTS}

\section{Vegetative growth characteristics}

\section{Plant height (cm)}

Data in Table (1) showed that raising the PBZ concentration caused a significant reduction in plant height. The highest significant reduction was obtained from the concentration of $120 \mathrm{mg} / \mathrm{L}$ PBZ which gave (43.85 and 42.79 $\mathrm{cm}$ ) in the first and second seasons, respectively. Table (1) also clarified that drench application of PBZ was more effective in plant height reduction. As for the effect of the combinations of PBZ and application method the highest significant decrease in plant height was obtained from the drench application of $120 \mathrm{mg} / \mathrm{L} \mathrm{PBZ} \mathrm{(} 24.09 \%$ and $30.77 \%$ ) in the first and second seasons respectively.

\section{Stem diameter (cm)}

The data recorded in Table (1) showed that stem diameter of treated plants with different concentrations of PBZ decreased significantly. The thinnest stem was obtained from the treatments $(90 \mathrm{and} 120 \mathrm{mg} / \mathrm{L}$ ) in the two seasons. Table (1) also clarified that there was insignificant difference between the two PBZ application methods. Concerning the interaction effect between PBZ concentration and application method the drench application of $120 \mathrm{mg} / \mathrm{L} \mathrm{PBZ}$ caused the thinnest stem which recorded $(0.42 \mathrm{~cm})$ in both seasons.

\section{Number of branches per plant}

Results presented in Table (1) showed that there was significant difference between the concentrations of PBZ. The treatment $60 \mathrm{mg} / \mathrm{L}$ caused the highest significant increase in the number of branches per plant ( 13.70 and 14.00 ) , while the treatment $120 \mathrm{mg} / \mathrm{L} \mathrm{PBZ}$ caused the lowest significant number of branches ( 11.37 and 10.67 ) in the first and second seasons, respectively. With respect to the effect of application method, the table showed that soil drench caused a significant decrease in the number of branches per plant in the first season, while in the second one there was insignificant difference between the two application methods. Concerning the interaction effect between application method and PBZ concentrations, the lowest significant number of branches was recorded after the treatment 90 and 120 $\mathrm{mg} / \mathrm{L}$ soil drench ( 8.56 and 9.17 ) in the first season and the treatment $90 \mathrm{mg} / \mathrm{L}$ soil drench (8.39) in the second one. 
Table (1). Average of plant height (cm), stem diameter (cm) and number of branches /plant of Pentas lanceolata plants as influenced by paclobutrazol concentrations (C), Method of application (M) and their interaction in the two seasons of 2013 and 2014.

\begin{tabular}{|c|c|c|c|c|c|c|c|}
\hline \multicolumn{2}{|c|}{ Treatments } & \multicolumn{2}{|c|}{$\begin{array}{l}\text { Plant height } \\
\text { (cm) }\end{array}$} & \multicolumn{2}{|c|}{$\begin{array}{c}\text { Stem diameter } \\
\text { (cm) }\end{array}$} & \multicolumn{2}{|c|}{$\begin{array}{c}\text { Number of } \\
\text { branches / plant }\end{array}$} \\
\hline $\begin{array}{c}\text { Method of } \\
\text { application }\end{array}$ & $\begin{array}{c}\text { Concentration } \\
(\mathrm{mg} / \mathrm{L})\end{array}$ & 2013 & 2014 & 2013 & 2014 & 2013 & 2014 \\
\hline \multirow{5}{*}{ Drench } & 0 & 51.15 & 52.72 & 0.65 & 0.64 & 12.00 & 11.50 \\
\hline & 30 & 46.93 & 48.04 & 0.60 & 0.59 & 13.20 & 12.67 \\
\hline & 60 & 45.33 & 45.89 & 0.60 & 0.61 & 14.50 & 14.67 \\
\hline & 90 & 42.34 & 44.44 & 0.50 & 0.48 & 8.56 & 8.39 \\
\hline & 120 & 38.83 & 36.50 & 0.42 & 0.42 & 9.17 & 8.67 \\
\hline \multicolumn{2}{|c|}{ Average of drench method } & 44.92 & 45.52 & 0.55 & 0.55 & 11.48 & 11.18 \\
\hline \multirow{5}{*}{ Spray } & 0 & 52.83 & 55.28 & 0.64 & 0.56 & 11.56 & 12.00 \\
\hline & 30 & 49.83 & 53.11 & 0.56 & 0.55 & 11.72 & 12.33 \\
\hline & 60 & 50.77 & 51.56 & 0.54 & 0.54 & 12.89 & 13.33 \\
\hline & 90 & 48.38 & 50.89 & 0.45 & 0.48 & 16.44 & 15.00 \\
\hline & 120 & 48.86 & 49.07 & 0.52 & 0.54 & 13.56 & 12.67 \\
\hline \multicolumn{2}{|c|}{ Average of spray method } & 50.14 & 51.98 & 0.54 & 0.53 & 13.23 & 13.07 \\
\hline \multirow{5}{*}{$\begin{array}{c}\text { Average of } \\
\text { application } \\
\text { methods }\end{array}$} & 0 & 51.99 & 54.00 & 0.65 & 0.60 & 11.78 & 11.75 \\
\hline & 30 & 48.38 & 50.58 & 0.58 & 0.57 & 12.46 & 12.50 \\
\hline & 60 & 48.05 & 48.39 & 0.57 & 0.58 & 13.70 & 14.00 \\
\hline & 90 & 45.36 & 47.67 & 0.48 & 0.48 & 12.50 & 11.70 \\
\hline & 120 & 43.85 & 42.79 & 0.51 & 0.48 & 11.37 & 10.67 \\
\hline \multirow{3}{*}{ L.S.D. at 0.05} & $\begin{array}{c}\text { Method of } \\
\text { application (M) }\end{array}$ & 0.95 & 0.97 & N.S & N.S. & 0.95 & N.S. \\
\hline & $\begin{array}{l}\text { Concentration } \\
\text { (C) }\end{array}$ & 1.50 & 1.53 & 0.053 & 0.047 & 1.51 & 0.05 \\
\hline & $M \times C$ & 2.13 & 2.17 & 0.074 & 0.067 & 2.14 & 0.07 \\
\hline
\end{tabular}

\section{Number of leaves per plant}

Data in Table (2) showed that the highest significant decrease in leaves per plant was obtained from the concentration $120 \mathrm{mg} / \mathrm{L}$ which gave (134.75 and 132.72) in the first and second seasons respectively. The table also clarified that foliar spray application of PBZ caused a significant decrease in number of leaves per plant. For the interaction effect of application method and PBZ concentration the treatment $120 \mathrm{mg} / \mathrm{L}$ PBZ as drench or foliar spray caused the lowest significant number of leaves per plant (136.5 and 133.11) and ( 133.00 and 132.33 ) in the first and second seasons respectively.

\section{Leaves dry weight $(g)$}

It is clear from Table (2) that the treatments 90 and $120 \mathrm{mg} / \mathrm{L} \mathrm{PBZ}$ resulted in the highest significant decrease in leaves dry weight which recorded $(7.20,6.43$ and $6.46,6.24 \mathrm{~g})$ in the first and second seasons respectively. The table showed that drench application of PBZ was more effective in reduction of leaves dry weight. For the effect of different combination of application method and PBZ concentration the drench application of 90 and $120 \mathrm{mg} / \mathrm{L} \mathrm{PBZ}$ resulted in significant decrease of leaves dry weight which were $(28.67 \%$, $23.58 \%)$ and $(27.04 \%, 24.61 \%)$ less than the control in the first and second seasons respectively. 


\section{Stem dry weight (g)}

Table (2) showed that the treatment $30 \mathrm{mg} / \mathrm{L}$ PBZ resulted in the highest significant decrease in stem dry weight which recorded (10.72 and $8.37 \mathrm{~g}$ ) for dry weight in the first and second seasons respectively. The table also cleared that foliar spray application of PBZ was more effective in reduction of stem dry weight. For the effect of different combination of application method and PBZ concentration the lightest stem dry weight $(8.90$ and $6.12 \mathrm{~g})$ in the first and second seasons respectively were obtained from foliar spray of $30 \mathrm{mg} / \mathrm{L} \mathrm{PBZ}$.

Table (2). Average of number of leaves /plant, leaves dry weight (g) and stem dry weight $(\mathrm{g})$ of Pentas lanceolata plants as influenced by Paclobutrazol concentrations (C), Method of application (M) and their interaction in the two seasons of 2013 and 2014.

\begin{tabular}{|c|c|c|c|c|c|c|c|}
\hline \multicolumn{2}{|c|}{ Treatments } & \multicolumn{2}{|c|}{$\begin{array}{c}\text { Number of } \\
\text { leaves/ plant }\end{array}$} & \multicolumn{2}{|c|}{$\begin{array}{l}\text { Leaves dry weight } \\
\text { (g) }\end{array}$} & \multicolumn{2}{|c|}{$\begin{array}{c}\text { Stem dry weight } \\
\text { (g) }\end{array}$} \\
\hline $\begin{array}{l}\text { Method of } \\
\text { application }\end{array}$ & $\begin{array}{c}\text { Concentration } \\
(\mathrm{mg} / \mathrm{L})\end{array}$ & 2013 & 2014 & 2013 & 2014 & 2013 & 2014 \\
\hline \multirow{5}{*}{ Drench } & 0 & 181.00 & 174.00 & 9.95 & 8.32 & 12.35 & 10.40 \\
\hline & 30 & 184.10 & 181.17 & 8.32 & 7.51 & 12.53 & 10.62 \\
\hline & 60 & 199.60 & 194.11 & 8.18 & 6.64 & 17.30 & 12.39 \\
\hline & 90 & 163.20 & 151.00 & 5.39 & 5.36 & 14.53 & 11.29 \\
\hline & 120 & 136.50 & 133.11 & 4.58 & 4.97 & 13.06 & 10.41 \\
\hline \multicolumn{2}{|c|}{ Average of drench method } & 173.00 & 167.00 & 7.28 & 6.56 & 13.96 & 11.02 \\
\hline \multirow{5}{*}{ Spray } & 0 & 180.30 & 172.33 & 10.19 & 8.29 & 12.64 & 10.49 \\
\hline & 30 & 171.00 & 162.83 & 9.10 & 8.14 & 8.90 & 6.12 \\
\hline & 60 & 152.30 & 150.15 & 9.06 & 7.90 & 9.28 & 6.19 \\
\hline & 90 & 144.70 & 142.33 & 9.01 & 7.55 & 9.83 & 7.54 \\
\hline & 120 & 133.00 & 132.33 & 8.28 & 7.51 & 9.89 & 8.56 \\
\hline \multicolumn{2}{|c|}{ Average of spray method } & 156.00 & 152.00 & 9.13 & 7.88 & 10.11 & 7.78 \\
\hline \multirow{5}{*}{$\begin{array}{l}\text { Average of } \\
\text { application } \\
\text { methods }\end{array}$} & 0 & 180.65 & 173.17 & 10.07 & 8.31 & 12.50 & 10.45 \\
\hline & 30 & 177.55 & 172.00 & 8.71 & 7.83 & 10.72 & 8.37 \\
\hline & 60 & 175.95 & 172.13 & 8.62 & 7.27 & 13.29 & 9.29 \\
\hline & 90 & 153.95 & 146.67 & 7.20 & 6.46 & 12.18 & 9.42 \\
\hline & 120 & 134.75 & 132.72 & 6.43 & 6.24 & 11.48 & 9.49 \\
\hline \multirow{3}{*}{$\begin{array}{l}\text { L.S.D. at } \\
0.05\end{array}$} & $\begin{array}{c}\text { Method of } \\
\text { application (M) }\end{array}$ & 2.78 & 1.74 & 0.58 & 0.31 & 0.51 & 0.44 \\
\hline & $\begin{array}{l}\text { Concentration } \\
\text { (C) }\end{array}$ & 4.39 & 2.75 & 0.91 & 0.48 & 0.81 & 0.69 \\
\hline & $\mathrm{M} \times \mathrm{C}$ & 6.21 & 3.89 & 1.29 & 0.68 & 1.14 & 0.98 \\
\hline
\end{tabular}

\section{Leaf area /plant $\left(\mathrm{cm}^{2}\right)$}

Table (3) showed that the treatments 90 and $120 \mathrm{mg} / \mathrm{L}$ PBZ (1812.46 and $\left.1920.40 \mathrm{~cm}^{2}\right)$ in the first season and the treatment $120 \mathrm{mg} / \mathrm{L}(1662.06 \mathrm{~cm}$ ${ }^{2}$ ) in the second season caused the highest significant reduction in leaf area. The soil drench of PBZ was more effective in reduction of leaf area. Concerning the interaction between the application method and PBZ concentrations the Table cleared that the treatment $120 \mathrm{mg} / \mathrm{L}$ as a soil drench caused the least leaf area which recorded (1264.42 and $1226.65 \mathrm{~cm}^{2}$ ) in the first and second seasons respectively. 


\section{Root characteristics}

\section{Roots dry weight}

Table (3) cleared that raising the PBZ concentrations caused a significant increase in roots dry weight . The highest significant root dry weight was obtained from the concentrations of 90 and $120 \mathrm{mg} / \mathrm{L}$ PBZ which gave $(10.58$ and $10.68 \mathrm{~g})$ in the first season and $(8.90$ and $9.53 \mathrm{~g})$ in the second one . The table also cleared that drench application of PBZ was more effective in increasing roots dry weight. Concerning the effect of the different combination of application method and PBZ concentration the table showed that the drench application of PBZ at 90 and $120 \mathrm{mg} / \mathrm{L}$ led to a significant increase of root dry weight which were ( $95.02 \%$ and $92.46 \%$ ) in the first season and $(61.97 \%$ and $73.62 \%$ ) in the second one .

\section{Flowering characteristics}

Concerning the flowering date (days) and flowers longevity (days), Table (4) showed that there were insignificant difference between treatments.

Table (3). Average of leaf area $\left(\mathrm{cm}^{2}\right)$ and roots dry weight (g) of Pentas lanceolata plants as influenced by paclobutrazol concentrations (C), Method of application (M) and their interaction in the two seasons of 2013 and 2014.

\begin{tabular}{|c|c|c|c|c|c|}
\hline \multicolumn{2}{|c|}{ Treatments } & \multicolumn{2}{|c|}{ Leaf area $\left(\mathrm{cm}^{2}\right)$} & \multicolumn{2}{|c|}{ Roots dry weight (g) } \\
\hline $\begin{array}{l}\text { Method of } \\
\text { application }\end{array}$ & $\begin{array}{l}\text { Concentration } \\
(\mathrm{mg} / \mathrm{L})\end{array}$ & 2013 & 2014 & 2013 & 2014 \\
\hline \multirow{5}{*}{ Drench } & 0 & 2769.72 & 2648.58 & 6.23 & 6.18 \\
\hline & 30 & 1480.83 & 1960.67 & 8.61 & 7.91 \\
\hline & 60 & 1562.69 & 1862.06 & 10.73 & 8.62 \\
\hline & 90 & 1312.95 & 1792.52 & 12.15 & 10.01 \\
\hline & 120 & 1264.42 & 1226.65 & 11.99 & 10.73 \\
\hline \multicolumn{2}{|c|}{ Average of drench method } & 1678.12 & 1898.10 & 9.94 & 8.69 \\
\hline \multirow{5}{*}{ Spray } & 0 & 2693.54 & 2617.08 & 6.71 & 6.09 \\
\hline & 30 & 2482.26 & 2432.64 & 8.00 & 7.40 \\
\hline & 60 & 2604.74 & 2054.34 & 8.16 & 7.43 \\
\hline & 90 & 2311.96 & 2188.21 & 9.01 & 7.78 \\
\hline & 120 & 2576.37 & 2097.47 & 9.36 & 8.33 \\
\hline \multicolumn{2}{|c|}{ Average of spray method } & 2533.77 & 2277.95 & 8.25 & 7.41 \\
\hline \multirow{5}{*}{$\begin{array}{l}\text { Average of } \\
\text { application } \\
\text { methods }\end{array}$} & 0 & 2731.63 & 2632.83 & 6.47 & 6.14 \\
\hline & 30 & 1981.55 & 2196.66 & 8.31 & 7.66 \\
\hline & 60 & 2083.72 & 1958.20 & 9.45 & 8.03 \\
\hline & 90 & 1812.46 & 1990.37 & 10.58 & 8.90 \\
\hline & 120 & 1920.40 & 1662.06 & 10.68 & 9.53 \\
\hline \multirow{3}{*}{ L.S.D. at 0.05} & $\begin{array}{c}\text { Method of } \\
\text { application (M) }\end{array}$ & 133.15 & 131.16 & 0.49 & 0.41 \\
\hline & Concentration & 210.53 & 207.39 & 0.77 & 0.65 \\
\hline & $M \times C$ & 297.74 & 293.29 & 1.09 & 0.92 \\
\hline
\end{tabular}


Table (4). Average of flowering date (days) and flowers longevity (days) of Pentas lanceolata plants as influenced by paclobutrazol concentrations (C), Method of application (M) and their interaction in the two seasons of 2013 and 2014.

\begin{tabular}{|c|c|c|c|c|c|}
\hline \multicolumn{2}{|c|}{ Treatments } & \multicolumn{2}{|c|}{$\begin{array}{c}\text { flowering date } \\
\text { (days) }\end{array}$} & \multicolumn{2}{|c|}{$\begin{array}{c}\text { flowers longevity } \\
\text { (days) }\end{array}$} \\
\hline $\begin{array}{l}\text { Method of } \\
\text { application }\end{array}$ & $\begin{array}{c}\text { Concentration } \\
(\mathrm{mg} / \mathrm{L})\end{array}$ & 2013 & 2014 & 2013 & 2014 \\
\hline \multirow{5}{*}{ Drench } & 0 & 274.22 & 284.89 & 36.13 & 32. \\
\hline & 30 & 275.34 & 299 & 35.63 & 24.89 \\
\hline & 60 & 276.2 & 297.89 & 41.77 & 29.45 \\
\hline & 90 & 281.33 & 293.67 & 34.67 & 32.00 \\
\hline & 120 & 281.11 & 291 & 33.90 & 36.67 \\
\hline \multicolumn{2}{|c|}{ Average of drench method } & 277.64 & 293.45 & 36.42 & 31.02 \\
\hline \multirow{5}{*}{ Spray } & $\mathbf{0}$ & 272.89 & 285 & 38.11 & 31.44 \\
\hline & 30 & 275.00 & 293.00 & 39.03 & 26.67 \\
\hline & 60 & 277.11 & 294.11 & 43.20 & 29.89 \\
\hline & 90 & 277.78 & 300.89 & 39.57 & 27.11 \\
\hline & 120 & 280.78 & 300.44 & 37.20 & 25.56 \\
\hline \multicolumn{2}{|c|}{ Average of spray method } & 276.71 & 294.73 & 39.42 & 28.13 \\
\hline \multirow{5}{*}{$\begin{array}{l}\text { Average of } \\
\text { application } \\
\text { methods }\end{array}$} & 0 & 273. & 285. & 37.12 & 31.78 \\
\hline & 30 & 275.17 & 296.06 & 37.33 & 25.78 \\
\hline & 60 & 276.67 & 296.00 & 42.49 & 29.67 \\
\hline & 90 & 279.56 & 297.28 & 37.12 & 29.56 \\
\hline & 120 & 280.95 & 296.06 & 35.55 & 31.12 \\
\hline \multirow{3}{*}{ L.S.D. at 0.05} & $\begin{array}{c}\text { Method of } \\
\text { application (M) }\end{array}$ & N.S & N.S & N.S & N.S \\
\hline & $\begin{array}{l}\text { Concentration } \\
\text { (C) }\end{array}$ & N.S & N.S & N.S & N.S \\
\hline & $M \times C$ & N.S & N.S & N.S & N.S \\
\hline
\end{tabular}

\section{Chemical composition}

1. Total chlorophyll content ( $\mathrm{mg} / \mathrm{g}$ fresh weight)

Data represented in Table (5)cleared that there was a significant increase after the application of different PBZ concentrations, the treatments 60,90 and $120 \mathrm{mg} / \mathrm{L}$ resulted in the highest increase in total chlorophyll content $(32.19,32.51$ and $33.05 \mathrm{mg} / \mathrm{g})$ in the first season and in the second one the treatment $90 \mathrm{mg} / \mathrm{L}$ caused the highest increase in total chlorophyll $(35.24 \mathrm{mg} / \mathrm{g}$ ).Drench application of PBZ was more effective in increasing the total chlorophyll content in both seasons. Concerning the effect of the interaction between the application method and PBZ concentration Table (6) showed that the highest chlorophyll content ( $83.58 \mathrm{mg} / \mathrm{g}$ ) was obtained after the soil drench of $120 \mathrm{mg} / \mathrm{L} \mathrm{PBZ}$ in the first season and soil drench of $90 \mathrm{mg} / \mathrm{L} \mathrm{PBZ}$ in the second one $(40.01 \mathrm{mg} / \mathrm{g})$. 


\section{Total carbohydrate content ( $\mathrm{mg} / \mathrm{g}$ dry weight of leaves)}

Data in Table (5) showed that the highest significant increase in total carbohydrate content was obtained after the treatment $90 \mathrm{mg} / \mathrm{L} \mathrm{PBZ}$ which recorded $(16.94 \mathrm{mg} / \mathrm{g})$ in the second season. Concerning the application method soil drench of PBZ was more effective in increasing total carbohydrate content. For the effect of different combination of application method and PBZ concentration Table (6) showed that were insignificant different between treatments.

\section{Leaves distortions}

Figure (1) illustrated that there was some leaves distortion after the treatment of $120 \mathrm{mg} / \mathrm{L}$ PBZ in both foliar spray and soil drench application method.

Table (5). Average of total Chlorophyll ( $\mathrm{mg} / \mathrm{g}$ fresh weight) in the two seasons of 2013 and 2014 and total Carbohydrate $(\mathrm{mg} / \mathrm{g}$ dry weight of leaves) in the season of 2014 of Pentas lanceolata plants as influenced by paclobutrazol concentrations (C) , Method of application (M) and their interaction in the two seasons of 2013 and 2014.

\begin{tabular}{|c|c|c|c|c|}
\hline \multicolumn{2}{|c|}{ Treatments } & \multicolumn{2}{|c|}{$\begin{array}{c}\text { Total } \\
\text { Chlorophyll } \\
\text { (mg/g fresh weight) }\end{array}$} & \multirow{2}{*}{$\begin{array}{c}\text { Total } \\
\begin{array}{c}\text { Carbohydrate } \\
\text { ( } \mathrm{mg} / \mathrm{g} \text { dry weight } \\
\text { of leaves) }\end{array} \\
2014\end{array}$} \\
\hline $\begin{array}{l}\text { Method of } \\
\text { application }\end{array}$ & $\begin{array}{c}\text { Concentration } \\
(\mathrm{mg} / \mathrm{L})\end{array}$ & 2013 & 2014 & \\
\hline \multirow{5}{*}{ Drench } & 0 & 24.57 & 26.65 & 15.35 \\
\hline & 30 & 27.50 & 29.28 & 16.02 \\
\hline & 60 & 35.62 & 33.00 & 16.17 \\
\hline & 90 & 34.49 & 40.01 & 17.81 \\
\hline & 120 & 38.58 & 34.39 & 16.03 \\
\hline \multicolumn{2}{|c|}{ Average of drench method } & 32.15 & 32.67 & 16.28 \\
\hline \multirow{5}{*}{ Spray } & 0 & 24.54 & 25.92 & 14.43 \\
\hline & 30 & 25.09 & 28.78 & 16.13 \\
\hline & 60 & 28.75 & 30.16 & 16.23 \\
\hline & 90 & 30.52 & 30.47 & 16.07 \\
\hline & 120 & 27.52 & 28.89 & 15.63 \\
\hline \multicolumn{2}{|c|}{ Average of spray method } & 27.28 & 28.84 & 15.70 \\
\hline \multirow{5}{*}{$\begin{array}{l}\text { Average of } \\
\text { application } \\
\text { methods }\end{array}$} & 0 & 24.56 & 26.29 & 14.89 \\
\hline & 30 & 26.30 & 29.03 & 16.08 \\
\hline & 60 & 32.19 & 31.58 & 16.20 \\
\hline & 90 & 32.51 & 35.24 & 16.94 \\
\hline & 120 & 33.05 & 31.64 & 15.83 \\
\hline \multirow{3}{*}{ L.S.D. at 0.05} & $\begin{array}{c}\text { Method of } \\
\text { application (M) }\end{array}$ & 0.80 & 0.87 & 0.92 \\
\hline & $\begin{array}{l}\text { Concentration } \\
\text { (C) }\end{array}$ & 1.27 & 1.38 & 1.46 \\
\hline & $M \times C$ & 1.79 & 1.95 & N.S \\
\hline
\end{tabular}



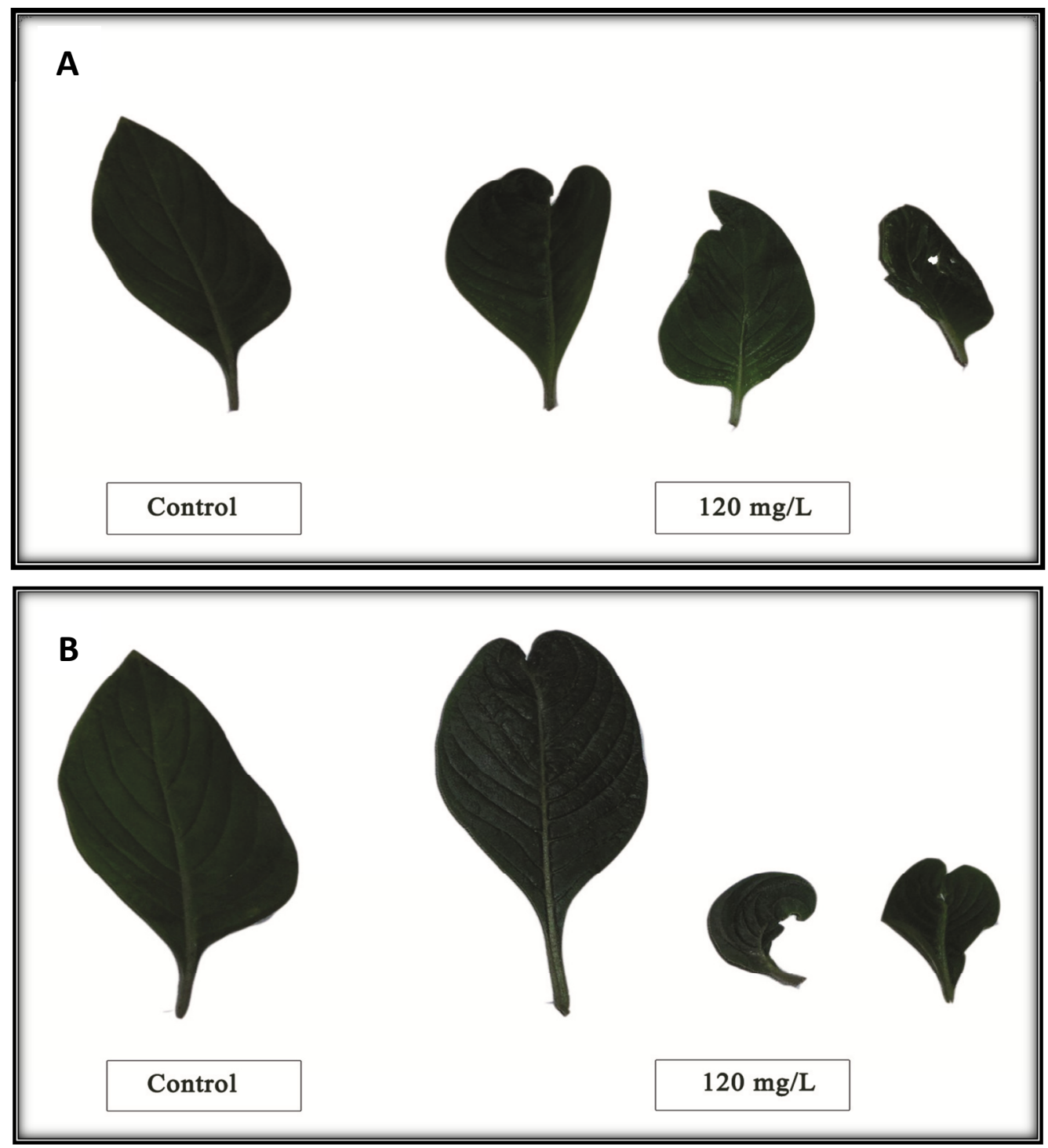

Figure (1). Leaves distortion after the treatment of $120 \mathrm{mg} / \mathrm{L} \mathrm{PBZ} \mathrm{(} \mathrm{A-}$ drench application) and (B- foliar spray )

\section{DISCUSSION}

The present study showed that the high dose of PBZ caused a significant reduction in most studied vegetative growth parameters. This reduction may be due to fact that paclobutrazol inhibits gibberellins (GAs) biosynthesis in plant (Rademacher, 2000 and Sponsel, 1995) and hence, reduces cell elongation and retards the plant growth. The reduction in vegetative growth parameters is in agreement with the results obtained by Lenzi et al. ( 2015) who found that PBZ treatments caused a significant reduction of plant height of four cultivars of Dianthus barbatus x chinesis. Also, Ahmad (2012) mentioned that PBZ treatments reduced plant height and leaf area of Hibiscus rosa-sinensis plants and Adam and Bożena (2005) on rhododendron and azalea shoot length. 
There was a significant increase in roots dry weight after the treatment of paclobutrazol. This increase may be explained on the rationale that its antagonize of GA biosynthesis or activity (GA is normally inhibitory to rooting) , (Davis and Sankhla, 1989) or an indirect effect resulting from shoot growth modification and a shift in carbohydrate allocation to the roots (Chaney, 2005) . This result is in harmony with those obtained by Chaturvedi, et al. (2009) on Saussurea costus.

Concerning the flowering parameters, the study showed that all the treatments caused insignificant difference compared to control .These results are in agreement with those obtained by Lenzi et al. (2015) on four cultivars of Dianthus barbatus $\mathrm{x}$ chinesis .

The increase in chlorophyll content by PBZ treatment could be explained on the basis of two facts: first, that the leaves of both treated and untreated plants may contain the same number of cells, but because the cells in treated ones are generally smaller, the chlorophyll is more concentrated inside the reduced cell volume. Second, there is also evidence that the amount of chlorophyll is actually increased due to increase in phytyl (an essential part of chlorophyll molecule), which is synthesized via the same terpenoid pathway as gibberellins (Dalziel and Lawrence, 1984). The obtained results are in agreement with those obtained by Lenzi et al. (2015) who mentioned that PBZ treatments enhanced leaf colour of four cultivars of Dianthus barbatus $x$ chinesis. And Ahmad (2012) who found that PBZ treatments increased chlorophyll content of Hibiscus rosa-sinensis .

The increase in carbohydrate content after the PBZ treatments may be due to the increase in chlorophyll content which leads to a consequent increase in total carbohydrates. This result is in harmony with Azza et al. (2014) on Schefflera arboricola plants.

There was some leaf deformation after the treatment of $120 \mathrm{mg} / \mathrm{L} \mathrm{PBZ}$ in both foliar spray or soil drench application method, this leaf deformation can be credited to the inhibitory impact of triazoles on gibberellin biosynthesis, which may cause harm or splitting of leaf primordia, unpredictable cell division or cell extension Mona (2001). These results are in agreement with those obtained by Matsoukis et al. (2001) who noticed some leaf distortion on Lantana camara plants treated with high concentrations of paclobutrazol and Joustra (1989) who found that paclobutrazol concentrations above approximately $125-250 \mathrm{mg} /$ $\mathrm{L}$ can cause leaf deformation on some rhododendron cultivars.

The difference in the suppression of growth with the method of application may be due to the difference in uptake of paclobutrazol by either the root or foliage and also the ability of the plant growth regulator to translocate in xylem and phloem (Keever et al., 1990). The primary translocation of paclobutrazol occurs through the xylem. Drench application of paclobutrazol was more effective maybe because of the rapid uptake of the plant growth regulator by the roots as the translocation occurs through the xylem quickly reducing the activity of gibberellic acid resulting in reduced stem length. Roots 
have fewer barriers that prevent entry of plant growth regulators. Foliar applied plant growth regulators first accumulate in the leaves and moves to the phloem and translocate into the xylem and takes more time before they become effective (Barrett and Bartuska, 1982). These results are in harmony with those obtained by Cramer and Brigden (1998) on Mussaenda erythrophylla potted plants

Conclusion

In conclusion, Pentas lanceolata can be used as a flowering pot plant since its height can be controlled by PBZ treatment. Paclobutrazol was applied as soil drench is considered more effective than foliar spray in reducing height. While the $120 \mathrm{mg} / \mathrm{L}$ of PBZ was more effective in producing short plants, it caused some leaf deformations. The treatment $90 \mathrm{mg} / \mathrm{L}$ was more effective in producing short and compact plants with no side effects on the plant appearance (Figure 2).
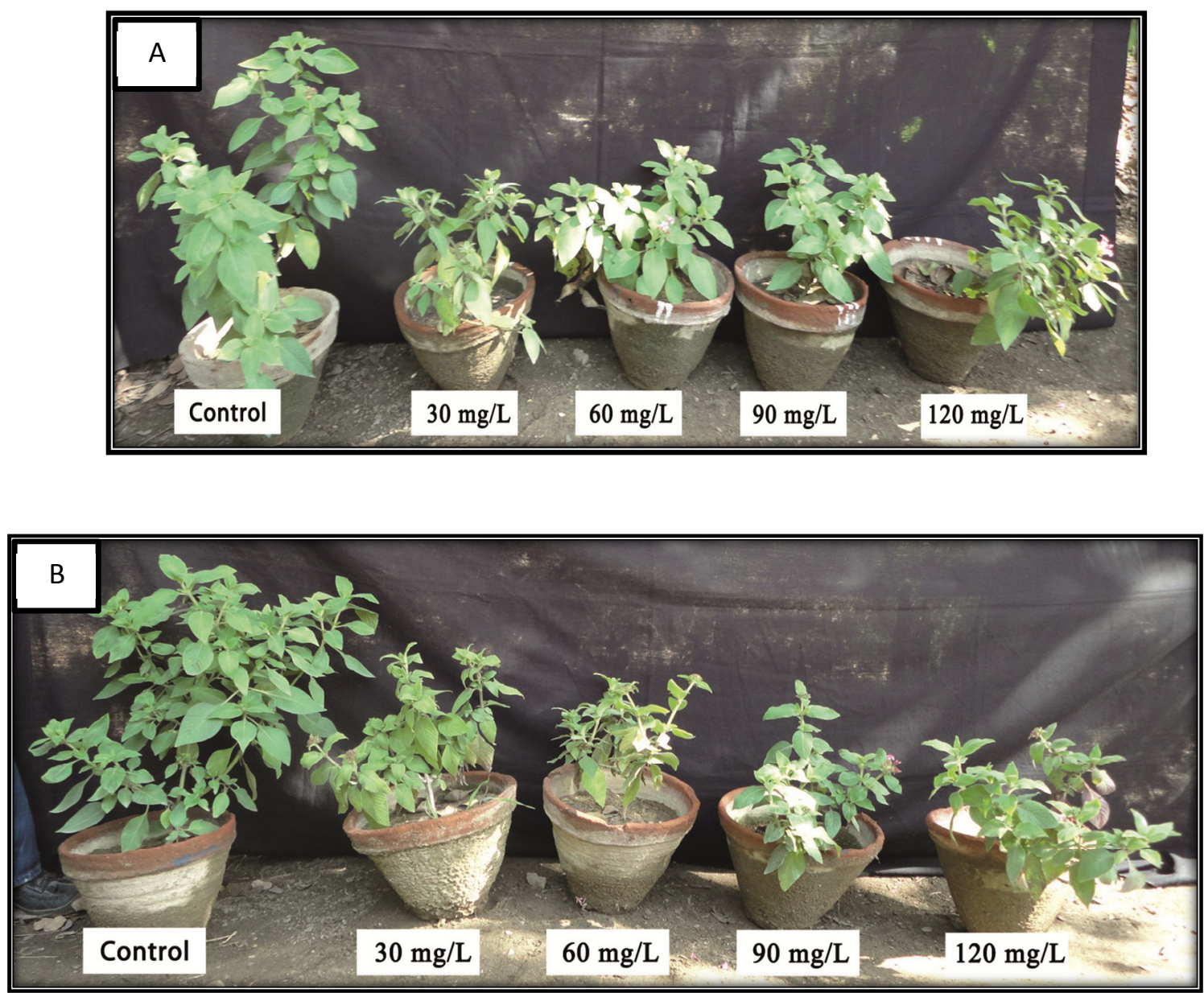

Figure (2). Effect of different paclobutrazol concentrations on the growth of Pentas lanceolata plants (A-drench application) and (Bfoliar spray ). 


\section{REFERENCES}

Adam, M. and M. Bożena ( 2005). Influence of growth retardants on growth and flower bud formation in rhododendron and azalea Dendrobiology, 54: $35-40$

Ahmad, N. (2012). Plant growth retardants effect on growth and flowering of potted Hibiscus rosa-sinensis L. J. Trop. Plant Physiol, 4 :29-40.

Azza, M.A.M. , G. A .A. Nahed, E. I. Effat, A.N. Amal and M. Samah (2014) . Effect of Gibberellic acid and paclobutrazol on growth and chemical composition of Schefflera arboricolaplants .Middle East J. Agric. Res., 3(4):782-792.

Barrett, J.E. and C.A. Bartuska. (1982). PP333 effects on stem elongation dependent on site ofapplication. HortScience, 17:737-738.

Chaney,W.R. ( 2005). Growth retardants: A promising tool for managing urban trees. Purdue Extension document FNR-252-W. Accessed on May 11, 2011 at: http://www.extension.purdue.edu/extmedia/FNR/FNR-252-W.pdf

Chaturvedi, A. K., R.K. Vashistha , P. Prasad and M. C. Nautiyal (2009). Effect of paclobutrazol and ethepon on Saussurea costus Nature and Science, 7(8) : $53-62$.

Cramer, C.S. and M.P. Brigden, ( 1998) . Growth regulator effects on plant height of potted Mussaenda 'Queen Sirkit'. HortScience, 33(1): 78-81.

Dalziel, J. and D.K. Lawrence (1984). Biochemical and biological effects of kaurene oxidase inhibitors such as paclobutrazol. British Plant Growth Regulatory Group Monograph, II : 43-57.

Davis, T. D. and N. Sankhla (1989). Effect of shoot growth retardants and inhibitors on adventitious rooting. In T. D. Davis, B. E. Haissig, and N. Sankhla, eds. Adventitious root formation in cuttings. Portland, OR: Dioscorides Press.:174-184.

Dubios, M., K. Gilles, J. Hamlton, P. Rebers, and F. Smith (1956). Colourimetric method for determination of sugars and related substances. Analytical Chemistry, 28(3): 350- 356.

Joustra, M.K. (1989). Application of growth regulators to ornamental shrubs for use as interior decoration. Acta Hort., 251 :359-369.

Keever , G.J. and W.J. Foster ( 1989). Response of two florist Azalea cultivars to foliar applications of a growth regulator. J. Environ. Horti., 7:56-59.

Keever, G.J.,W.J. Foster, and J.C. Stephenson. (1990). Paclobutrazol inhibits growth of woody landscape plants. J. Environ. Hort., 84:41-47.

Lenzi, A., M. Nannicini, P. Mazzeo and A. Baldi (2015). Effect of paclobutrazol in potted plants of four cultivars of Dianthus barbatus $\times$ chinensis. Europ. J. Hort. Sci, 80(2), 87-93.

Lever, B.G, S.J. Shearing and J.J. Batch (1982). PP333 - a new broadspectrum growth retardant. Proceedings of British Crop Protection Conference-Weeds. British Crop Protection Council, Croydon,: 3-10.

Matsoukis, A.S. , A. Chronopoulou-Sereli, I. D. Dimopoulos, and A. Kamoutsis ( 2001). Response of Lantana camara L. subsp. camara to paclobutrazol and shading .Can. J. Plant Sci. , 81: 761: 764 
Menhenett, R. and G.R. Hanks (1982). Comparisons of a new triazole retardant PP333 with ancymidol and other compounds on pot-grown tulips. Plant Growth Regulation, 1: 173-181.

Mona A. Sorour (2001). Effect of uniconazole on vegetative and flowering growth improvement in Jacobinia carnea Nichole plants M Sc. Thesis , Fac. of Agric . Alex .Univ. Egypt .

Mongrand, S., A. Badoc, B. Patouille, C. Lacomblez, M. Chavent and J. Bessoule (2005). Chemotaxonomy of the Rubiaceae family based on leaf fatty acid composition J. Phytochemistry, 66: 549-559.

Moran, R. ( 1982) . Formula determination of chlorophyll pigment extracted with N,N diethyl formamide, plant Physiol ., $69: 1376-1381$.

Rademacher, E. (2000). Growth retardants: Effects on gibberellin biosynthesis and other metabolic pathway. Annual Review of Plant Physiology and Molecular Biology, 51: 501-531.

Sanchita, G.H. (2015). Effect of growth retardants on quality production of pot mums J. Hill Agr.,6(1): 16-23.

Snedecor , G. W. and W. Cochran (1989). Statistical Methods, $8^{\text {th }}$ ed. lowa State University Press.

Sponsel , V.M. (1995). The biosynthesis and metabolism of gibberellins in higher plants. In Plant Hormones: Physiology, Biochemistry, and Molecular Biology, edited by Davis, p.j. (2 ${ }^{\text {nd }}$ ed.) Dordrecht: Kluwer Academic Pub.

Tsegaw, T., P.S. Hammes and J. Robberste ( 2005). Paclobutrazol-induced leaf, stem and root anatomical modifications in potato. HortScience, 40(5): 1345-1346.

Whealy, C.A., T.A. Nell and J. E. Barett (1988). Plant growth regulator reduction of bypass shoot development in azalea. HortScience, 23:166167.

$$
\begin{aligned}
& \text { الملخص العربي } \\
& \text { تأثير الباكلوبيوترازول وطريقة اضافته على نباتات البنتس } \\
& \text { أسماء محمد طه و منى عبد الحميا سرور } \\
& \text { فرع بحوث نباتات الزينة بأنطونيادس - الإسكندرية - معهد بحوث البساتين - مركز البحوث الزراعية }
\end{aligned}
$$


الباكلوبيوترازول غير معنوي على الصفات الزهرية المدروسة أما بالنسبة للوزن الجاف للجذور ومحتوى النبات من

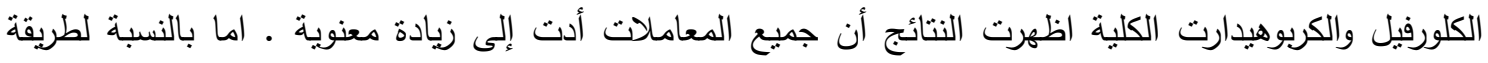

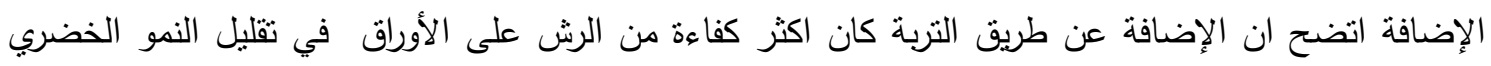
وزيادة وزن الجذور ومحتوى النبات من الكلورفيل والكربوهيدارت.

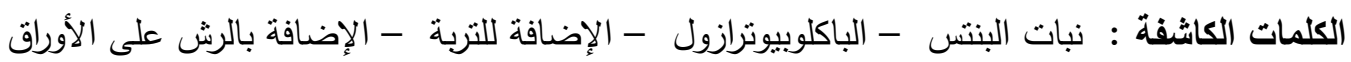

